\title{
A STUDY ON WORK LIFE BALANCE AMONG WOMEN LABOR IN GARMENT UNITS OF NCR, INDIA
}

\author{
Dr. Ajit Kumar Khare \\ Professor, National Institute of Fashion Technology, Mumbai, India
}

Anupam Kapoor

$\mathrm{PhD}$ Research Scholar, National Institute of Fashion Technology, New Delhi, India.

\begin{abstract}
The female labor force participation in the garment industry has increased considerably, due to which it becomes difficult for them to balance work and family commitments. The condition gains more importance in a male dominant society such as India where there are stereotypical roles assigned to the genders. This study aims to explore different influencing factors on women's work and family roles in the lower socio-economic strata of Indian cultural environment. The research identifies various factors impacting happiness at home \& productivity at work, and also happiness at work \& productivity at home. The study is timed to perfection considering the strenuous efforts undertaken by Indian Govt., in skill India initiatives. The methodology adopted for the study was descriptive research design. Data were collected from 133 women workers through questionnaire method in NCR, India. In the present study, statically tools such as percentage analysis, chi-square, and T-test were used for the analysis. The paper finds out different factors related to work and life that affect both aspects of working women in the garment units. The methodology helped to analyze data about challenges faced by women workers to achieve work-life balance.
\end{abstract}

Keywords: Gender, Women labor, fashion industry, work life balance, India

Cite this Article: Dr. Ajit Kumar Khare and Anupam Kapoor, A Study on Work Life Balance among Women Labor in Garment Units of NCR, India International Journal of Management, 10 (1), 2019, pp. 19-25.

http://iaeme.com/Home/issue/IJM?Volume=10\&Issue=1

\section{INTRODUCTION}

India has come up as one of the dominant garment exporting and producing nations of the world. The Indian garment industry comprises of almost one trillion units. Out of the total garments produced, $33 \%$ of knitwear and almost $20 \%$ of its wovens, both by volume and value, enlists in export markets. The ratio of exports to domestic markets from the total production 
according to Yasbek, 2004 is 1:3 by volume, implies that $75 \%$ garments produced in India are for domestic market. The nature of the garment industry is purely labor-intensive. Its importance includes bringing foreign exchange through exports. A crucial feature of the garment industry is that women comprise of major work force. Due to the ever - expanding, variable and disseminated nature of the industry, it is complex to get an accurate assessment of their concrete figures. However, according to CMIE (Centre for Monitoring Indian Economy) in 1999, the industry provided employment to about 15 million people, of which almost 90 per cent is women (Vergese, 1999). Whereas in 2017 the estimates indicated more 6,500 textile factories currently operating in India and an estimated female workforce of more than 35 per cent in north India (Moyne, 2017).

The portraiture of women being week and helpless is not new and has been carried over since the historical periods. In ancient times, women were a subject of underestimation in all walks of life and were restricted to household chores. Since the rise of industrialization era, families were compelled to scatter from locality in pursuit of a livelihood. Women embraced jobs were still answerable to their household obligations. It is due to this reason that work life balance becomes difficult for them as they confront lots of issues while sustaining both, their job and family life. Overburdening at workplace and playing different roles simultaneously is considered to be stannous and hence requires attention. The females discover methods and means to keep themselves unaffected from pressure. They manage these multiple roles so as to be able to be lucrative on all walks of life. During this process, most of the times they fail to give appropriate and necessary importance to their own health and wellbeing. (Pathak and Gupte, 2016).

\section{LITERATURE REVIEW}

Study of work life balance, internationally and nationally have been limited to studying the middle class, upper middle class and entrepreneurs. Some researchers (Bashir \& Ramay (2008) have been attempted to emphasize the significance of work life policies. "To reduce the workfamily conflict and efficient in improving attitudes, work-life programs are found to be more effective" (Konrad \& Mangel, 2000). Work places must be created and bring into practice those benefits and strategies to help employees balance their work and lives (e.g., pliable work schedules, dependent care supports)" (Thompson, Andreassi, \& Prottas, 2003). Bruce Weinstein (2009) stated that going to and fro between different roles responsibilities regarding the families and anticipations of the organization and consistent endeavor to sustain a balance at work can have serious adverse results on the life of a person. Therefore, it is critical for workforce to maintain an appropriate balance between work and their personal lives. This will be beneficial for them not only to attain their personal and professional aims but also well the organization they are associated to. The concern of Indians with regards to balancing work and life have overshadowed worries about the slow pace economy, according to the bi-annual global consumer opinion survey by market research company The Nielsen Co.

Woods, D. (2011) in his paper, "Work Life balance: Global Survey reveals differences between what employers say and do" throws light on the problem of work life balance. Belief of people in the top management in US, UK and Germany is that, as a policy issue, employee wellbeing and overall health practices are important. In their paper, "Leaders recognize to stress", Dan forth S. (2011) have elaborated on the issue of work stress. Majority of the leaders now know that there is a decline in productivity and performance due to employee stress. Not long ago, employee stress was dealt at an individual level, but lately it has gained more importance as a macro-level issue. Stress management sweeps in from the top level and filters to the subordinates where the top-level employees require stress managements related issue recognition in their employees which in turn help their subordinates handle their stress. Jennifer 
and Susan (2010), in their article, found high frustration levels in full time vs part time managers due to their lack of mobility and career progression.

Studies in India, also have avoided studying work life balance of the worker class. Tiwari, 2017 studied work life balance of female employees in private institutions. Pathak and Gupte, 2016 Work Life Balance of Working Women in The Upper Middle Class in Pune City and found that the working women face a lot of issues right from maintaining relations, parenting to doing office work on time. There have been few studies related to the garment industry in India too. Thulasimani et. al in 2010 studied work life balance amongst managers of garment units in Tamilnadu State, India. Results indicated managers are not completely successful due to their present working hours, working environment and increase in products prices, work load, responsibilities in work and decrease of job security due to recession. Meenakshisundaram and Panchanatham in 2012 studied on work life balance of employees with reference to a garment industry- unit and found out that the organization is showing keen interest in career life of the employees and work load has been kept reasonable, by sharing the duties and responsibilities among the employees.

\section{OBJECTIVES OF THE STUDY}

The literature hence establishes a gap and a need for research work life balance amongst women of the lower socio-economic strata of the society working in garment units, hence leading to the below objectives.

- To study the factors that affect the work life of working women in the garment units,

- To study the factors that affect the personal life of working women in the garment units and

- To determine relationship between the factors that affect work and life of working women in the garment units.

\section{METHODOLOGY}

An exploratory study was conducted to ascertain facts with approximately 20 respondents working in different apparel manufacturing factories in NCR and in the southern part of the country. The response of the participants varied but lead to a formal study with above objectives to investigate the issue at a greater length. A schedule consisting demographic data related to the respondents such as age, gender, marital status, experience, qualification, income level as well questions using Likert-type scale from 1 to 5 (with response options Strongly Disagree, Disagree, Neither Agree nor Disagree, Agree and Strongly Agree and Always affects, Affects many times, Affects sometime, rarely affects, Doesn't affect at all) to understand the importance of various factors impacting work life balance was used.

Female working at sewing machine operative's level in factories situated in NCR participated in the survey. In response to this survey, total 133 valid responses were used for further analysis.

Table 1 Demographic profile of the Respondents

\begin{tabular}{|c|c|c|}
\hline \multirow{2}{*}{ DESCRIPTION } & CATEGORIES & PERCENTAGE \\
\hline \multirow{2}{*}{ Age } & Less than 25 years & $38.9 \%$ \\
\cline { 2 - 3 } & $25-30$ years & $32.1 \%$ \\
\hline
\end{tabular}


A Study on Work Life Balance among Women Labor In Garment Units of NCR, India

\begin{tabular}{|c|c|c|}
\hline & $30+$ years & $29 \%$ \\
\hline \multirow{3}{*}{ Education } & Possessed diploma/ certificate & $32.6 \%$ \\
\hline & Undergraduate & $20.5 \%$ \\
\hline & Graduate. & $47 \%$ \\
\hline \multirow{3}{*}{ No. of years of experience } & Less than 2 years of experience & $38.6 \%$ \\
\hline & $2-4$ years of experience & $37.9 \%$ \\
\hline & more than 4 years of experience & $23.5 \%$ \\
\hline \multirow{3}{*}{ Marital status } & Single & $28 \%$ \\
\hline & Married with no kids & $16.7 \%$ \\
\hline & Married and having kids. & $55.3 \%$ \\
\hline \multirow{4}{*}{ Travel time to work } & less than 15 minutes & $25 \%$ \\
\hline & $15-30$ minutes & $38 \%$ \\
\hline & $31-60$ minutes & $20 \%$ \\
\hline & more than 60 minutes & $17 \%$ \\
\hline \multirow{3}{*}{ Working hours per week } & $48-52$ hours /week & $50 \%$ \\
\hline & $53-57$ hours/week & $14 \%$ \\
\hline & more than 58 hours/week & $36 \%$ \\
\hline
\end{tabular}

\section{FINDINGS}

\subsection{Work related factors}

Work related factors held great importance to the respondents. Approx. 22\% said that travel time from home sometimes affects their work. More than 54\% agree to the fact that their organization does help them to cope up with stress. This seem to go with the findings of Dan forth S. (2011) where they found out that stress management is a micro -issue for companies now. More than $40 \%$ agree to the fact that they feel that their ill health relates to stress due to work. $30 \%$ agree to the fact that they often get worried about work when not at work. $58 \%$ agree to the fact that family support matters to them in balancing work-life aspect. More than 


\section{Dr. Ajit Kumar Khare and Anupam Kapoor}

$66 \%$ agree to the fact that their supervisor appreciates their efforts. More than $77 \%$ agree to the fact that they are satisfied with their relationship with my fellow colleagues.

\subsection{Personal life related factors}

Personal life related factors were another header that held importance in the findings. Almost $69.2 \%$ said that they are able to balance work and family life. More than $44 \%$ agree that they feel exhausted sometimes. Approx. 24\% said that they feel exhausted always/many times. More than $41 \%$ agree that they suffer from stress or health related problems. $45 \%$ said that compulsory over time affects in balancing work \& family commitments. More than $38 \%$ said that long working hours affects sometimes in balancing work \& family commitments. Approx. $38 \%$ said that negative attitude of peers at work place affects sometimes in balancing work \& family commitments. Approx. $47 \%$ said that negative attitude of supervisors affects sometimes in balancing work \& family commitments. Approx. 40\% said that work pressure affects sometimes in balancing work \& family commitments. More than $68 \%$ agree to the fact that they feel satisfied supporting their family financially. More than $46 \%$ agree to the fact that they often feel tired, depressed or stressed due to work. More than $47 \%$ agree to the fact that they often miss family due to pressure at work. $24 \%$ agree to the fact that they are absent during most of the important events of personal life.

\section{RESULT ANALYSIS}

$\mathrm{Chi}$ - Square analysis found that there is a significant association between commuting time and work life balance. This means that higher commuting time from home to work results in poor work life balance. There is no significant relationship between years of experience and hours spent at work in a week by the respondents. One-way ANOVA analysis found that higher the age more is the problem in balancing work and family commitments due to Negative attitude of supervisors. Findings in relation to age also indicated that higher the age more is the problem in balancing work and family commitments due to work pressure. Also, it is found that respondents having family with kids find difficulty in balancing work and family commitments due to compulsory overtime. Lastly, the results also showed that the respondents having family with kids find difficulty in balancing work and family commitments due to long working hours.

\section{CONCLUSION}

Managing both the fronts is the only option that women have. During the study it was observed that more than $68 \%$ respondents feel satisfied in supporting their family financially and more than $75 \%$ feel that their family members understand the working situations and its criticality in today's time.

We know that with age, balancing work along with family commitments gets more difficult due to work pressure and negative attitude of supervisors. Married women who have kids find it even more laborious to strike a balance between personal engagements and those at work, thus the Organization needs to identify these problems and work towards solving them. Excessive work pressure due to long working hours or overtime is one of the major reasons for deterioration in the health of the workers. Feeling detached from their dear ones can costs the employees their mental peace. Even when they are satisfied for being the financial supporters for their families, when the supervisor appreciates their work and their family understands the criticality of their job, the organization must come up with ideas to help employees cope up with stress, because at a macro level, a satisfied employee with a happy home has more probability of contributing to nation building in a positive way than those who are depressed, tired or frustrated with their lives. 
To deal with this pressing issue, organizations should introduce 'Work Life Benefits' Programme initiatives, where they provide means of flexible working hours, alternative work arrangements, leave policies and benefits in lieu of family care responsibilities. These will have a direct effect on employee attitude and behaviour, organizational commitment and retention rate of workers. This way all employees will be able to manage their work and their family roles in a better way simultaneously. The company should keep a proper account and take care of employees work load to balance the work life. The management should also identify other problems which may be hindering the work life balance. The company should provide better recreation facilities, work environment, counseling and increments for over-time and other additional responsibilities to motivate the employees. This will also help in the overall professional growth of the worker.

Work-life balance is about creating a productive work culture where the potential for tensions between work and other parts of people's lives is minimized. If an organization takes into consideration the happiness quotient of its employee's domestic lives as well, it will directly result in better productivity and smooth flow of work throughout the organizations. With the Organization Comes First mantra outliving its utility, it is high time we realize that the focus is actually needed somewhere else.

\section{REFERENCES}

[1] Bashir, S., \& Ramay, M. I. Determinants of organizational commitment: a study of information technology professionals in Pakistan. Journal of Behavioral and Applied Management, 9(2), 2008, pp 226 - 238

[2] Bohle, P., Quinlan, M., Kennedy, D., \& Williamson, A, Working hours, work-life conflict and health in precarious and" permanent" employment. Revista de Saúde Pública, 38, 2004, pp 1925 .

[3] Bruce Weinstein, The Ethics of Work-Life Balance, A special report, Business weak.com, 2009

[4] Dan forth, S, Leaders need to recognize stress. Wicked Local Dedham (Online). Retrieved September 20, 2017 from www.dailynewstranscript.com, 2011

[5] Sheela Varghese, Employment of Women in the Garment Industry, Discussion paper, URL: http://www.krpcds.org, 1999

[6] Konrad, A. M., \& Mangel, R. The impact of work-life programs on firm productivity. Strategic management journal, 21(12), 2000, pp 1225-1237.

[7] Mathew, R. V., \& Panchanatham, N, an Exploratory Study on the Work-Life Balance of Women Entrepreneurs in South India. Asian academy of management journal, 16(2), 2011, pp $77-105$.

[8] Meenakshisundaram, M., \& Panchanatham, N, A study of work life balance of employees with reference to a garment industry-unit. AMET International Journal of Management, 3(1), 2012, pp $52-58$.

[9] Pathak, A., \& Gupte, A, Work Life Balance of Working Women in the Upper Middle Class in Pune City. KHOJ: Journal of Indian Management Research and Practices, (special issue) 2016, pp 145-151.

[10] Rehman, S., \& Azam Roomi, M, Gender and work-life balance: a phenomenological study of women entrepreneurs in Pakistan. Journal of Small Business and Enterprise Development, 19(2), 2012, pp 209-228.

[11] Thompson, C. A., Beauvais, L. L., \& Lyness, K. S, when work-family benefits are not enough: The influence of work-family culture on benefit utilization, organizational attachment, and work-family conflict. Journal of Vocational behavior, 54(3), 1999, pp 392-415. 


\section{Dr. Ajit Kumar Khare and Anupam Kapoor}

[12] Thulasimani, K. K., Duraisamy, M., \& Rathinasabapathi, S. S, A study on work life balance amongst managers of garment units in Tamilnadu State, India. Journal of Human Sciences, 7(2), 2010, pp 445-460.

[13] Dr. S. Jayaraman, Dr. J. Suhashini, U. Geetha and E. Manju, A Study on Impact Of Job Related Factors On work Life Balance Of Automobile Sector Workers In Dindigul District, International Journal of Mechanical Engineering and Technology, 9(11), 2018, pp. 17321740 .

[14] Tiwari, M. Work Life Balance of Female Employees in Private Institutions, Gwalior: An Investigation. 19, 2017, pp $35-38$.

[15] Tomlinson, J., \& Durbin, S, Female part-time managers: work-life balance, aspirations and career mobility. Equality, Diversity and Inclusion: An International Journal, 29(3), 2010, pp 255-270.

[16] N. Mohan, N. Prabha and P. Mohanraj, Work Life Balance through Flexi work Arrangements: Empirical Study on Bank employees, International Journal of Management (IJM), Volume 1, Number 2, July-Aug, pp. 53-61.

[17] Woods, D., Work-life balance: Global survey reveals differences between what employees say and do, https://www.hrmagazine.co.uk/article-details/work-life-balance-global-surveyreveals-differences-between-what-employers-say-and-do, 2011

[18] Yasbek, P. The business case for firm-level work-life balance policies: a review of the literature. Wellington, UK: Department of Labor, January, 2004. 